\title{
Patent ruling expands access to genetic tests and treat- ments
}

$\mathrm{T}$ he United States Supreme Court has stripped away three decades of patent protection for human genes in a decision likely to mean broadly cheaper genetic testing and, possibly, accelerated discoveries.

Affirming that no one can corner the market on nature, the ruling promises to bring an expensive set of tests for breast and ovarian cancer within reach for many more high-risk women.

Mere hours after the justices ruled last week, one company announced it would conduct those tests for US\$950, down from the $\$ 3000-\$ 4000$ that it commonly cost when Utah-based Myriad Genetics had exclusive rights to the genes. Other companies and universities have also said they will begin offering the tests.

The decision opens important areas of research to companies that have been frozen out by patents covering roughly $20 \%$ of human genes, which has raised hope for scientific advances in the longer term. But there are concerns, too, that the loss of patent protection could make the payoff for pioneering researchers potentially less lucrative and thus inhibit discovery.

On balance, the medical establishment and the government have welcomed the outcome. And the biotechnology industry was heartened by the court's decision to uphold patents on synthetic DNA even though it invalidated rights to natural human genes.

"The decision represents a victory for all those eagerly awaiting more individualized, gene-based approaches to medical care," said Dr. Francis Collins, director of the National Institutes of Health and a geneticist.

"Such approaches form the cornerstone of the rapidly emerging field of personalized medicine, in which diagnostic, therapeutic and preventive strategies can be tailored to each person's unique genetic makeup."

The ruling was the first of a pair

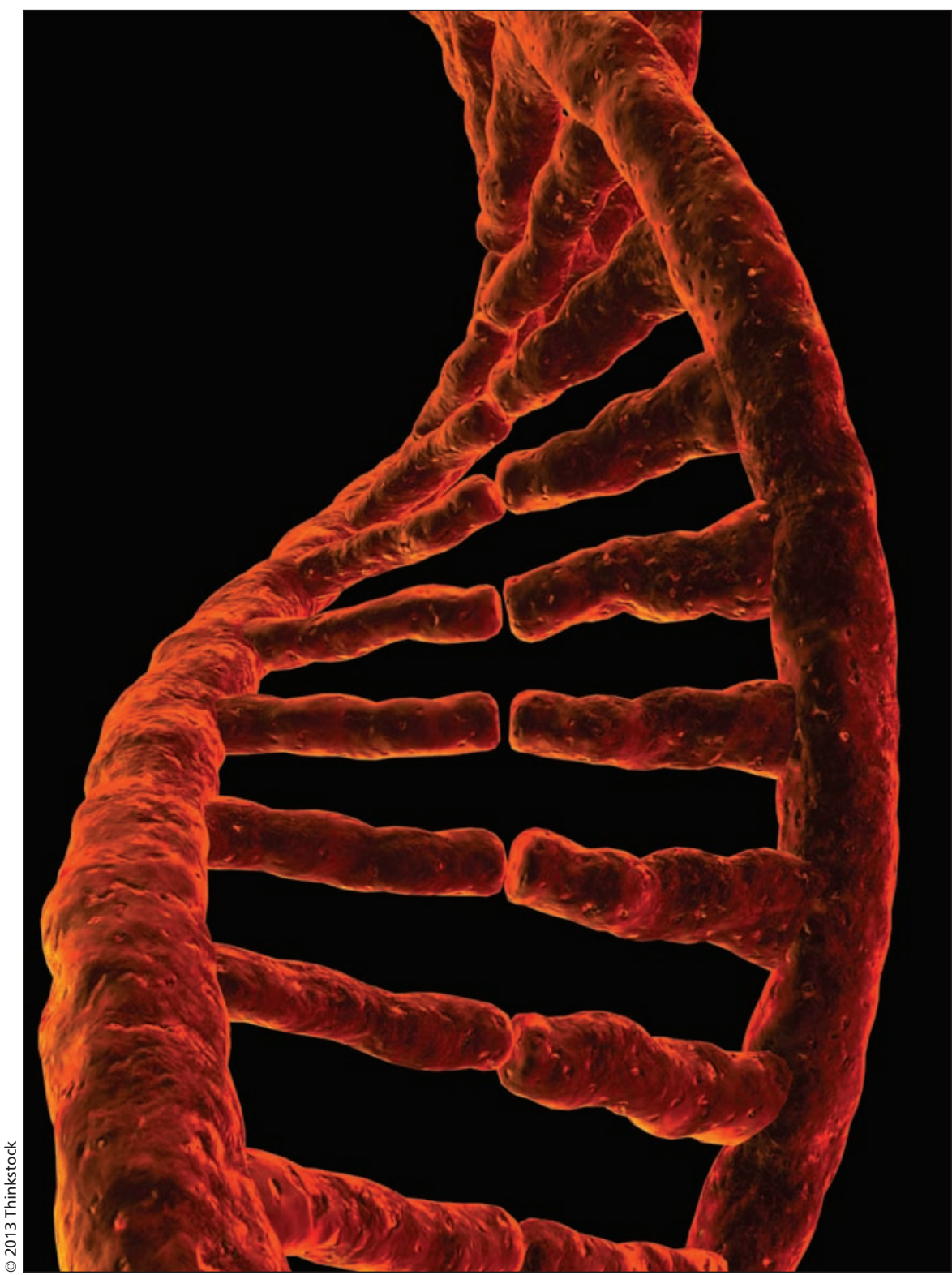

The court decision opens significant areas of research to companies that have been frozen out by patents covering roughly $20 \%$ of human genes.

that promise to shape the accessibility of medicine. The court recently ruled 5-3 that "pay to delay" arrangements in the drug industry may be illegal in some cases and can be challenged by the government.

Under such arrangements, usually struck when the outcome of a patent lawsuit would be in doubt, a drug company pays a hefty sum to a generic competitor to delay its marketing of a cheap equivalent, typically for a few years. The government says such deals can delay the availability of affordable drugs.

The ruling on gene patents (www .supremecourt.gov/opinions/12pdf/12 
-398_1b7d.pdf) was unanimous, unusual for an ideologically divided court known for split decisions on blockbuster cases. The same justices upheld President Barack Obama's universal health care law by just one vote.

At issue were the BRCA1 and BRCA2 genes. Mutations in either one greatly increase the risk of breast cancer and, to a lesser but still significant extent, ovarian cancer.

Actress Angelina Jolie's discovery that she had inherited a BRCA1 genetic mutation contributed to her decision to have a preventive double mastectomy earlier this year.

Given the scientific complexities of the case, the justices used many everyday analogies to explore whether Myr- iad deserved a patent for isolating natural DNA.

A skeptical Justice Sonia Sotomayor said that if she had discovered a new way to bake cookies, she'd gain rights to the treats but could not patent the salt, flour and eggs that go into them. That, she suggested, was what Myriad wanted.

Someone who discovers a medicinal wildflower in the Amazon, others said, cannot own the plant but merely a unique medical formulation made from it.

Gregory A. Castanias, representing Myriad, likened the DNA in question to a baseball bat - a product that is not highly manipulated in manufacturing but still a distinct product worthy of a patent.
"A baseball bat doesn't exist until its isolated from a tree," he told the court. "But that's still the product of human invention to decide where to begin the bat and where to end the bat."

The justices didn't buy that argument. Justice Clarence Thomas, author of the court's ruling, concluded that Myriad had not created or altered the genetic information encoded in the genes but had merely isolated the genes, and could not exercise ownership rights.

When it comes to the building blocks of life, the court affirmed, anyone can play. - Cal Woodward, Washington DC

CMAJ 2013. DOI:10.1503/cmaj.109-4531 